\title{
Development of Science Learning with Spiritual Approach to Improve the Understanding of Science Concepts in Muslim Boarding School
}

\author{
Ridho Yanuar Dwi Primayudha \\ Science Education \\ Universitas Negeri Surabaya \\ Surabaya, Indonesia \\ ridhoprimayudha@gmail.com
}

\author{
Wasis Wasis \\ Science Education \\ Universitas Negeri Surabaya \\ Surabaya, Indonesia
}

\author{
Sri Poedjiastoeti \\ Science Education \\ Universitas Negeri Surabaya \\ Surabaya, Indonesia
}

\begin{abstract}
This study aims to develop science learning device with a scientifically oriented spiritual approach that is feasible with the criteria of validity, practicality, and effectiveness to improve understanding of the concept of science students in boarding schools based junior high school. The results showed: 1) the developed learning device has validity and valid categories so it is feasible to be used in the learning, 2) the results of the implementation of science learning devices that have been developed very well, 3 ) cognitive ability is seen from the completeness of the indicator categorized thoroughly with the value of $n$-gain of 0.71 means very high. Overall, it can be concluded that the developed science learning device is feasible and can improve the understanding of science concept of learners in Pesantren based junior high school.
\end{abstract}

Keywords—science lesson; spiritual orientation; understanding of science concept

\section{INTRODUCTION}

Understanding the concept of science that associated with the verses of the Qur'an can be seen on the learner's worksheet. In the worksheet, this learner is obtained that most of the learners able to play the role and able to discuss the results of experiments and able to link the results of discussion with verses of the Quran. In the results of the first worksheet discussion where learners are able to create and associate characteristic tables with the titus bode law. The pesantren-based junior high school is faced with a dualism of demands in which the graduates are enrolled with sufficient academic ability and the graduates must have a high spiritual level in accordance with the demands of the Qur'an. One of the messages from Pesantren Amanatul Ummah caregivers that all learners who are under the auspices of Amanatul Ummah educational institutions, one of them SMP based Pesantren Amanatul Ummah expected to get value above KKM that is 80 . In result study of science grade 8 in chapter System of Solar System get mean equal to 81 . This is still not in accordance with the expectations of the boarding school cottage so that researchers try to improve science learning outcomes where one of them is to improve understanding of the concept of science with a spiritual orientation so as to improve the results of good learning and spiritual.

In general, the learning process uses the 2013 curriculum with a scientific approach, but which distinguishes the other learning process that is in the process of learning execution, student worksheet (LKPD) and handbook of learners (BPPD) are all oriented spiritually. The process of learning in understanding the concept of science is associated with the Qur'anic verse, student worksheets are associated with the Qur'anic verses and in the handbook therein are linked with the verses of Al Quran. This is the main attraction for learners so that the motivation of learners increases in line with learning outcomes.

There are limits in this study where researchers in addition to wanting stages of understanding the concept of science, researchers also do not forget the stages of remembering and applying. This is because the stages of remembering, understanding, and applying are the steps that must be passed by each learner. Stages of understanding are stages that are higher level than remember so to go to the stage of understanding, need to go through the stages of remembering. The stages of applying are the next stage after going through the stages of understanding. Therefore, in this study carried out the stages of remembering, understanding, and applying by focusing on the understanding stage of understanding the concept of science.

\section{METHODS}

Development of learning device in this research is using 4D (Four-D Model) development model. The subject of this development research is the science-learning device with a spiritual-oriented scientific approach that has been developed. The subject of learning device implementation is $8^{\text {th }}$ grade of Junior High School students based on Pesantren Amanatul Ummah. Learning device development follows the following path, (1) analyzing $\mathrm{KI}$ and $\mathrm{KD}$, (2) analyzing learners, (3) 
analyzing learning, (4) formulating indicators and learning objectives, (5) preparing preliminary tests, (6) choosing learning strategies, (7) selecting media and teaching materials, (8) develop a learning device, (9) validation by an expert, (10) revise by expert, (11) carry out trial I with a limited number, (12) revise II, (13) conduct trial II on one $8^{\text {th }}$ grade, and (14) revision III.

\section{RESULTS AND DISCUSSION}

\section{A. Learning Device Validity}

The science-learning device with a spiritual-oriented scientific approach that has been developed by researchers has been reviewed and assessed by experts before being implemented. Results of validated syllabus have been categorized valid with percentage of achievement of $88.46 \%$; validation of the learning implementation plan developed has been categorized valid with the percentage of achievement of $87.5 \%$; validation of learners worksheets that have been developed are categorized valid with percentage of achievement of $90 \%$; and validation of handbooks of learners that have been developed are categorized valid with a percentage of $88.93 \%$.

\section{B. Practically of Learning Devices}

The implementation of learning by scientific approach can be said to be valid with the percentage of validity of $93 \%$. This suggests that learning with a scientific approach is appropriate for use in learning. The phase of questioning and collecting data obtained the highest average of 3.8. The table is modified in graphical form to facilitate the researcher in reading sata so that it is presented in graph form as follows:

GRAPH I. IMPLEMENTATION OF LEARNING WITH A SCIENTIFIC APPROACH

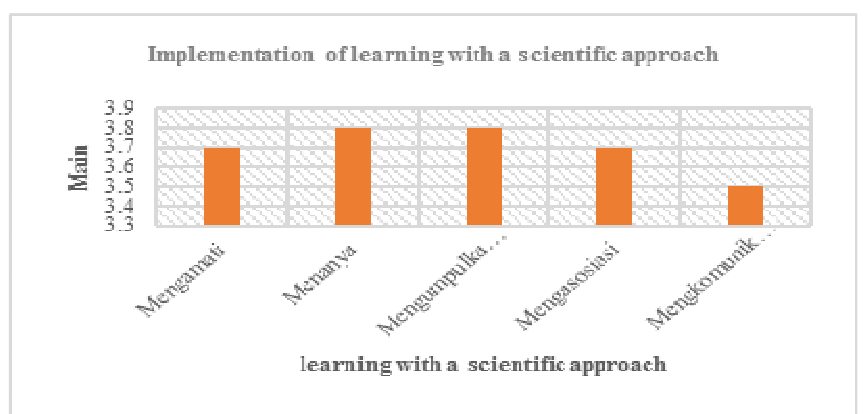

The graph obtained information that the phase that gets the lowest score is the communicating phase. This is because the students still need to practice to present the results of the discussion and public opinion. Phases that get the highest average value of the phase of questioning and collecting data. This is because in the phase of questioning, learners are very enthusiastic in asking about the solar system system associated with the Quran. Most of the learners are very interested in the science of the solar system because it requires an abstract level of thought and is associated with verses of the Qur'an so as to make the spirit of learning more learners. Abstractive thinking ability is the ability to find problem solving without the presence of the object of the problem is real, in the sense that learners do the activities of thinking symbolically or imaginatively. There are so many questions related to the solar system and its relation to the Qur'an. In the phase of collecting data, learners do the activities of role play. This role play aims to know the circulation of the sun with its planets and the circulation of the moon, the earth, and the sun. This is the main attraction because learners know firsthand how the sun, earth, and moon rotate and evolve. In addition, learners also relate the results of the discussion of role playing with Qur'anic verses where each group of learners there who bring the book of the Quran in this learning so that students apply the interpretation directly from Al Quran and translation. This indirectly embeds the concept more because learners apply the accepted concept as seen on Quran so that the level of understanding improves.

\section{Effectiveness of Learning Devices}

This research was conducted two tests that is test of preliminary test and final test. From preliminary test results obtained that of 30 complete learners meet the completeness criteria as much as 2 learners so that the percentage of unresponsiveness is $93 \%$. This is because learners on the initial test still use the initial knowledge at the previous level. In the final test activity with 30 students obtained $100 \%$ completeness with an average value of 86 . This has been in accordance with the statement of the Pondok Pesantren Board that in the implementation of learning, learners are expected to score above the criteria mastery. There is no difference in the value of mastery criteria between junior-based pesantren and junior high school in general. However, the difference is the implementation of learning. Implementation of learning that is associated with Qur'anic verse covers the process of implementation of learning, student worksheets, and handbook of learners.

Based on the results of the concept of understanding science, it obtained n-gain of 0.71 with high category. From the n-gain results, obtains high value of the phase of questioning and collecting data. From this phase can be obtained that the phase of questioning and collecting data can improve the understanding of the concept of science. This is in line with Piaget's theory where piaget says that learning will be more successful when adapted to the stage of cognitive development of learners. This study has been adapted to the cognitive development of learners residing in pesantren life. Piaget also said that learners are given the opportunity to conduct experiments and supported by the interaction of peers. This is in line with Piaget's theory which suggests that the phase-inquiry studies that are part of peer-to-peer interaction and data collection are part of the experiment in which the inquiring phase and the information gathering phase have the highest mean values. In the phase of the questioning where students try to obtain information. Then in the phase of collecting data which is the process of transformation and test the relevance and accuracy of knowledge so that the understanding of the concept of science to be increased. This is obtained not apart from the implementation of learning tools that have been prepared neatly. High value of achievement is obtained based on the implementation of learning.

According to [1], understanding is the result of learning, for example, the learner can explain with the composition of his own sentence for what he read or hear, giving another example of what the teacher has exemplified and using other 
case implementation instructions. Learning outcomes can not only be demonstrated by tests [2], but learning outcomes can be demonstrated by conceptual understanding. Understanding is the ability of a person to understand or understand something after something is known and remembered. In other words, understanding understands something and can see it in many ways. So it can be concluded that learners are able to understand something and can provide an explanation or give a more detailed description of what is learned by using its own language.

Religious or spiritual education in science according to [3] is not a stand-alone subject or a taught value, but rather an effort to cultivate religious values integrated in science subjects. Aspects to be considered in understanding the concept of science-oriented is to explicitly link rspiritual values in learning planning, implementation of learning and assessment of learning tailored to the characteristics of science. Spiritual attitudes become an important component in the aspect of human life. Where religion will lead to a better life, religion will color the character of one's shalih. Religion will lead the heart to be willing to do good things [4].

Understanding the concept of science is closely related to the verses of the Qur'an. It is proven that the concept of science that is taught and associated with Al Quran can make learners motivated and improve their learning spirit [5]. Learners get additional information more because learners are not only able to understand the concept of science but learners are able to associate the concept of science with Quranic verse so that spiritual orientation increases.

Based on the above description obtained that science learning with spiritual-oriented scientific approach can improve understanding of science concept of learners. This can be proved in accordance with the explanation where with the understanding of the concept of science associated with the verses of Al Quran can increase learners' motivation and enthusiasm in achieving academic so that learning achievement will also get better.

Based on the above descriptions, the findings are (1) the developed Learning science that oriented with spiritual learning device include (a) Syllabus with the prevalence rate of $88.46 \%$; (b) Learning Implementation Plan (RPP) with the prevalence rate of $87.50 \%$, (c) Student Activity Sheet (LKPD) with a $90.00 \%$ validity rate, and (d) the Student Handbook (BPPD) with a validity rate of $88.93 \%$. It can be concluded that understanding the concept of science learners with good categorization so well worthy to be used in learning, (2) the developed learning science- spiritual oriented device include the implementation of learning with a validity level of $93 \%$, (3) the results of comprehension of the concept of science with $100 \%$ completeness level and the response of learners is seen from the value of n-gain of 0.71 with very high category so that it can be said that science learning devices with spiritualoriented scientific approach to improve understanding of the concept of science is very effective for applied in learning.

\section{CONCLUSION}

Based on the findings of the research, it can be concluded that science-learning device with developed scientific-oriented spiritual approach feasible to improve understanding of science concept in junior high school-based pesantren. Teachers are expected to be able to master the interpretation of the verses of the Quran so it is easy to associate the concept of science with Qur'anic verses and for further research, is expected in learning given the verses of Al Quran, then associated with the concept of science so that understanding the concept of science will be better.

\section{ACKNOWLEDGEMENT}

I would like to thank Universitas Muhammadiyah Sidoarjo for giving me an opportunity to publish my paper.

\section{REFERENCES}

[1] Sudjana, N. 1995. Penilaian Hasil Proses Belajar Mengajar. Bandung: PT. Remaja Rosdakarya.

[2] Reeves, T. C., \& Okey, J. R. (1996). Alternative assessment for constructivist learning environments. Constructivist learning environments: Case studies in instructional design, 191-202.

[3] Susilawati. 2012. Karakter Religius Pembelajaran IPA. Jurnal Pendidikan Islam Vol. XVII No. 1

[4] Mursali, S. 2013. Pengembangan Perangkat Pembelajaran Biologi SMA Berbasis Metakognitif Untuk Meningkatkan Kemampuan Kognitif dan Mengembangkan Perilaku Berkarakter Siswa. Jurnal UNESA: Volume 01 Nomor 01, 0-216

[5] Atwell, E., Habash, N., Louw, B., Abu Shawar, B., McEnery, T., Zaghouani, W., \& El-Haj, M. (2010). Understanding the quran: A new grand challenge for computer science and artificial intelligence. $A C M$ BCS Visions of Computer Science 2010. 